УДК $327(541.35+549.1)$ «20/21»

DOI: 10.26693/ahpsxxi2019.01.032

\title{
ОСОБЛИВОСТІ НЕПАЛЬСЬКО-ПАКИСТАНСЬКИХ ВІДНОСИН У ХХ - НА ПОЧАТКУ ХХІ СТОЛІТТЯ
}

\author{
Ірина Габро, \\ e-mail:irngabro@gmail.com \\ ORCID: https://orcid.org/oooo-ooo1-8215-7615 \\ Чорноморсъкий національний університет імені Петра Могили, \\ Украӥна, 540о3, м. Миколаїв, вул. 68 Десантників, 10 \\ Єлизавета Кабачек, \\ e-mail: lizazagorodnaya0705@gmail.com \\ ORCID: https://orcid.org/oooo-0002-0746-6239 \\ Чорноморський національний університет імені Петра Могили, \\ Украӥна, 540о3, м. Миколаїв, вул. 68 Десантників, 10
}

Відносини Пакистану та Непалу були мінливими протягом XX - початку XXI століття: від дружніх відносин до розриву дипломатичних відносин. Але Непал $\epsilon$ стратегічно важливою територією для Пакистану. Незважаючи на погані транспортні зв'язки, Пакистан надає пріоритетне значення для збільшення торгівлі та пожвавлення відносин з Непалом, оскільки такі подї виведуть Індію з цієї області, геополітична карта світу зазнає змін і Індія втратить своє домінуюче положення. I Пакистан, $і$ Непал відіграють активну роль у СААРК, відображаючи, по суті, їх спільне бажання сприяти миру та прогресу в Південній Азї.

Ключові слова: Пакистан, Непал, Південна Азія, СААРК, економічне співробітництво, політичне співробітництво

Постановка проблеми. Відносини Непалу та Пакистану є прикладом динамічних відносин двох нерівноцінних кравців, в яких втім сильніший гравець (Пакистан) не тисне на слабшого (Непал), а вибудовує відносини із ним. У непальськопакистанських відносинах спрацьовує низка чинників, адже Непал знаходить на перетині інтересів Пакистану із Індією та Китаєм. Ці чинники то покращували, то погіршували відносини між двома країнами. Саме тому актуальним є дослідження особливості непальсько-пакистанських відносин у XX - на початку XXI столітті.

Аналіз попередніх досліджень та публікацій. Особливості непальськопакистанських відносин у XX столітті розкривають та аналізують науковці іноземного походження. Здебільшого, це праці американських та пакистанських науковців. До пакистанців, які досліджували дану проблему відносяться: С. Ахмед ${ }^{12}$, С. Амін Т. Деленіч4. С. Ахмед вивчав міжнародні відносини Пакистану із різними державами, зокрема з Непалом. Науковець окремо виділив відносини Непалу та Пакистану під час індо-пакистанської війни. Процес творення пакистанської дипломатії вивчався С. Аміном. Відносини Пакистану та Непалу у рамках СААРК досліджував Т. Делініч.

\footnotetext{
${ }^{1}$ Ahmad, S. (2007). Pakistan's Foreign Policy. Lahore: Daily Nation.

2 Ahmed, S. (2009). Foreign Policy of Pakistan and Policy Making Process. In M. Ahmar, Foreign Policy Making Process; A Case Study of Pakistan. Islamabad: University of Karachi: Department of International Relations in Collaboration with Hanns Seidel Foundation.

3 Amin, S. (2009). Historical Basis of Pakistan's Foreign Policy Making Process. Islamabad: University of Karachi: Department of International Relations in Collaboration with Hanns Seidel Foundation.

4 Delinic, T. (2011). SAARC-25 Years of Regional Integration in South Asia. KAS International Reports.
} 
До групи американських вчених, які займались вивченням даного питання, автор відносить В. Гудсона5, С. Калера ${ }^{6}$. Зокрема, В. Гудсон досліджував історію та еволюцію відносин Непалу та Пакистану у XX ст. С. Каллер займався вивченням питання ефективності СААРК і співпраці Пакистану й Непалу у рамках цієї організації у XX ст.

Метою дослідження $\epsilon$ дослідити відносини між Непалом та Пакистаном у XX на початку XXI ст.

Завдання роботи:

- дослідити особливості непальсько-пакистанських відносин в політичній, економічній і культурно-гуманітарній сферах у XX - на початку XXI ст.;

- розкрити проблеми у відносинах між Непалом та Пакистаном у XX - на поч. XXI ст.

Методи та прийоми дослідження. Методологічним підгрунтям дослідження стали принципи наукового пізнання - історизму, об’єктивності, системності, багатофакторності та детермінізму. Так, завдяки принципу історизму на основі науковокритичного використання різноманітних джерел було проаналізовано зміст та етапи співробітництва Непалу з Пакистаном. Принцип багатофакторності дозволив вивчити усі фактори, які впливали на відносини між Непалом та Пакистаном протягом XX - на початку XXI ст. В ході дослідження було застосовано сукупність загальнотеоретичних і спеціальних методів. До загальнотеоретичних методів, які застосовані авторами, належать методи аналізу і синтезу, індукції та дедукції, абстрагування та узагальнення, а також групування. Для розв'язання визначених наукових завдань і всебічного вивчення поставленої проблеми були застосовані системний, синхронний, історикопорівняльний, компаративний, а також метод зовнішньополітичного прогнозування.

Пакистансько-непальські відносини сягають початку 1950-х pp. Пакистан було утворено в серпні 1947 р. і протягом 5 років він встановив дружні відносини з Непалом.

Варто зауважити, що у 1950 р. Непал встановив дипломатичні відносини із Індійським Союзом та не встановлював їх із Пакистаном та Китаєм. Через невдоволення населення держави зростаючим індійським впливом, уряд Непалу розпочав розвиток відносин з Пакистаном. Початкові контакти між двома країнами почалися у 1952 р. на засіданнях Плану Коломбо, а потім на Бандунзькій конференції в 1955 році7. Згодом міністр закордонних справ Пакистану Хамід уль-Хак Чодрі взяв участь в церемонії коронації короля Махендра в 1956 р. Офіційні дипломатичні відносини між двома країнами були встановлені 29 березня 1960 р. ${ }^{8}$

Король Махендра зробив стратегічний крок, встановивши дипломатичні відносини з новоутвореним Пакистаном. Він вважав геополітичне становище Непалу складним і з тих пір розглядав Пакистан як близького друга, який підтримує суверенітет і незалежність Непалу. Уже в наступному році король Махендра відвідав Пакистан. Президент Аюб Хан зробив візит у відповідь до Катманду в 1963 р., і саме під час цього візиту дві країни вирішили заснувати дипломатичні представництва в столицях своїх держав. Під час візиту лідери обох країн підписали угоду про створення режиму найбільшого сприяння в торгівлі. У 1963 р. Пакистан і Непал дійшли згоди прибрати тарифи при торгових операціях, а також до поставки транспортних засобів до Непалу через порт Читтагонг у Східному Пакистані (нині Бангладеш) і встановленню повітряного сполучення. Ці домовленості знизили економічну залежність Непалу від Індії9.

5 Hudson, V. (2008). The History and Evolution of Foreign Policy Analysis. In S. Smith (ed.), Foreign Policy: Theories, Actors, Cases (pp. 47-56). Oxford University Press.

${ }^{6}$ Kaler, S. (2016). Successes and Failures of SAARC. Indian journal of applied research, 6 (3), 212213.

7 Nepal-Pakistan friendship and cultural Association. (n.d.). Pakistan-Nepal Relations. Retrieved from http://npfca.org.np/history-of-nepal-pakistan-relations

${ }^{8}$ Government of Nepal - Ministry of Foreign Affairs (2019). Nepal-Pakistan Relations. Retrieved from https://mofa.gov.np/nepal-pakistan-relations/

9 Library of Congress. (n.d.). Pakistan and Bangladesh. Retrieved from http://countrystudies.us/nepal/66.htm 
3 тих пір були проведені різні візити на високому рівні. Участь у них брали наступні особи. 3 Непалу король Махендра, король Бірендра, колишній наслідний принц Дипендра, прем’єр-міністри Нагендра Прасад Ріал, Сурія Бахдур Тхапа, Марич Ман Сингх, Гірджа Парсад Койрала і Шер Бхадурі Деуба, які неодноразово відвідували Пакистан. 3 боку Пакистану побували президенти Аюб Хан, Яхья Хан, Фазл-е-Елахі Чаудхрі, Зія-уль-Хак, Первез Мушарраф і прем'єр-міністри Мухаммад Хан Джанжо, Мохтарма Беназір Бхутто Шахід, Шаукат Азіз і прем’єр-міністр Сайед Юсуф Раза Гілані. Крім того, було здійснено багато взаємних візитів на рівні міністрів двох держав. У 1962 р. Непал відкрив посольство в Пакистані, а в 1975 р. було відкрито почесне непальське консульство в Карачі ${ }^{10}$.

31962 р. розпочались торговельні відносини між двома країнами, коли непальська делегація відвідала Пакистан і підписала угоду про взаємну торгівлю ${ }^{11}$. В якості подальших заходів з розвитку торгових відносин міністр торгівлі Пакистану відвідав Катманду в травні 1965 р. Згодом міністр торгівлі Непалу (г-н Нагендра Прасад Ріджал) і глава Комісії з планування відвідали Пакистан в 1966 і 1969 роках відповідно ${ }^{12}$. У той час непальський експорт до Пакистану включав деревину, насіння олійних культур і лікарські трави, при цьому Непал імпортував фармацевтичні продукти, текстиль, спортивні товари і т.д.

Наприкінці 1970-х років обидві країни відчули необхідність переглянути торгову угоду 1962 р. Відповідно, міністр торгівлі Пакистану відвідав Непал в 1979 році для обговорення нової торгової угоди. Нову торговельну угоду було підписано в липні 1982 р.13 Проте двостороння торгівля залишилась незначною через географічні обмеження Непалу та відмови Індії від транзитного сухопутного маршруту до Непалу. 3 тих пір торгові делегації регулярно здійснюють взаємні візити. Непальські бізнесмени відвідують щорічний торговий форум у Карачі. Однак торгівля між двома країнами не відповідає існуючому потенціалу й їм необхідно подвоїти свої зусилля у цьому напрямі.

Слід зауважити, що Непал став однією із перших держав, яка визнала незалежність Бангладеш. Хоча під час Індо-пакистанської війни 1971 р. Непал офіційно підтримував нейтралітет. У відповідь на цей недружній крок Ісламабад розірвав дипломатичні відносини з Катманду у 1972 р.14 Згодом дипломатичні відносини були відновлені.

Варто відмітити, що від початку встановлення дипломатичних відносин між Непалом і Пакистаном, обидві країни дотримувалися однакової позиції майже у всіх міжнародних питаннях та ситуаціях. Від Камбоджі до Афганістану і від Палестини до ірансько-іракської війни обидві країни завжди дотримувалися однакових поглядів. Обидві країни також підтримували позицію один одного з основних політичних питань.

Пакистан підтримав вступ Непалу до Організації Об’єднаних Націй (1955 р.) і згодом його кандидатуру на непостійне місце в Раді Безпеки ООН (1968 р.) Пакистан також був прихильником пропозиції Непалу про зону миру. Пакистан був першою країною, яка підтримала дану ініціативу Непалу, заявивши, що ця пропозиція $\epsilon$ цінним внеском у справу миру в регіоні. Непал підтримав пропозицію Пакистану про створення зони, вільної від ядерної зброї в Південній Азії у 1974 р. і завжди голосував за це в Організації Об'єднаних Націй. Непал також підтримав членство Пакистану в Русі неприєднання (РН). Обидві країни також підтримували те, щоб Індійський океан був оголошений зоною миру15.

${ }^{10}$ Government of Nepal - Ministry of Foreign Affairs (2019). Nepal-Pakistan Relations. Retrieved from https://mofa.gov.np/nepal-pakistan-relations/

${ }^{11}$ Embassy of Pakistan Kathmandu. (n.d.). Pak-Nepal Economic Relations. Retrieved from http://pakembnepal.org.pk/pak-nepal-economic-relations/

12 Ibidem.

13 Amin, S. (2009). Op. cit., 84.

${ }^{14}$ Hudson, V. (2008). Op. cit., 48.

${ }^{15}$ Sattar, A. (2010). Pakistan's Foreign Policy (1947-2009): A Concise History. Karachi: Oxford University Press, 112. 
Важливою подією у двосторонніх відносинах стало підписання у 1983 р. Угоди про створення спільної економічної комісії, яку підписали міністри фінансів двох країн. Відповідно до цієї Угоди обидва уряди погодилися вжити всіх необхідних заходів для зміцнення і розвитку економічного і технічного співробітництва між двома країнами на взаємовигідній основі у сферах економіки, торгівлі, промисловості, сільського господарства, освіти, науки і техніки, зв’язку, культури і туризму. Комісія під співголовуванням міністра фінансів Непалу і міністра економіки Пакистану провела свою першу зустріч в Катманду в 1983 р..й другу в Ісламабаді у 1984 р. За останні 25 років комісія збиралась всього два рази. Ї̈ зусилля призвели до підписання різноманітних двосторонніх угод в сферах сільського господарства, авіаперевезень, торгівлі, уникнення подвійного оподаткування, культури і туризму.

Відповідно до Угоди про культуру 1970 р. уряд Пакистану надає непальським студентам освітні послуги, навчання та стипендії в областях банківської справи, сільського господарства, торгівлі, медицини, машинобудування, фармацевтики і т. д. Згідно з програмою технічної допомоги Пакистану (РТАР), уряд Пакистану щорічно надає стипендії Непалу в галузі медицини, фармації та інженерії. У Пакистані 500 студентів-непальців, які навчаються в галузі медичної науки, техніки, фармації, інформаційних технологій, соціальних наук, менеджменту та масової комунікації. Пакистан забезпечує довгострокову і короткострокову підготовку урядовцям Непалу ${ }^{16}$. До 1970 р. Пакистан у рамках плану Коломбо навчав дев'яносто сім пілотів і авіаційних інженерів Непалу. В даний час непальським студентам щорічно пропонується кілька стипендій для навчання в професійних коледжах Пакистану на додаток до навчання в банківському секторі і курсам по комунікації в засобах масової інформації.

Непал та Пакистан співпрацюють у межах СААРК - Асоціації регіонального співробітництва країн Південної Азї - із року її заснування у 1985 р. СААРК була створена Бангладеш, Шрі-Ланкою, Бутаном, Мальдівськими Островами, Індією, Непалом і Пакистаном з метою сприяння економічному, культурному, соціальному розвитку і спільній самозабезпеченості країн-членів. Афганістан отримав членство в організації у 2007 р. У число країн, що мають статус спостерігача, входять США, Європейський союз, Китай, Японія, Австралія, Південна Корея, Іран, М'янма і Маврикій ${ }^{17}$.

Особливою є співпраця Непалу та Пакистану у рамках СААРК у сфері науки ${ }^{18}$. Принципи СААРК визнали, що грамотність $є$ фундаментальним правом людини і фундаментом для навчання протягом усього життя, яке приймається через освіту. Вона $\epsilon$ абсолютно необхідною для соціального і людського розвитку у його здатності трансформувати життя. Для індивідів, сімей і суспільства це є інструмент розширення можливостей для покращення здоров'я, доходу і відносин зі світом. Тому Пакистан та Непал приділяють особливу увагу підвищенню рівня грамотності в регіоні шляхом підвищення якості освіти. Неграмотність була головною перешкодою для економічного розвитку та соціальної емансипації, і що викорінення неграмотності в регіоні.

Під час Другого саміту СААРК (Бангалор, 16-17 листопада 1986 р.) глави держав або урядів підтвердили велике значення посилення участі людей для забезпечення успішної регіональної співпраці. Держави-члени підкреслили необхідність сприяння посиленню контактів між народами регіону через такі дії, як регулярний і частий обмін науковцями, науковцями, художниками, авторами, фахівцями та бізнесменами, а також сприяння туризму.

На третьому саміті (Катманду, 2-4 листопада 1987 р.) лідери заснували кафедри СААРК, стипендії для держав-членів СААРК для просування освітніх закладів у регіоні СААРК. Під час Четвертого саміту (Ісламабад, 29-31 грудня 1988 р.) лідери вирі-

${ }^{16}$ Government of Nepal - Ministry of Foreign Affairs (2019). Nepal-Pakistan Relations. Retrieved from https://mofa.gov.np/nepal-pakistan-relations/

17 Kaler, S. (2016). Op. cit., 212.

${ }^{18}$ South Asian Association for Regional Cooperation (2019). Education security and culture. Retrieved from http://saarc-sec.org/areas_of_cooperation/area_detail/education-security-andculture/click-for-details_11 
шили, що освіта може бути включена як узгоджена сфера співпраці, оскільки всі діти є основним засобом розвитку людських ресурсів. Тому дітям слід приділяти найвищий пріоритет у плані національного розвитку.

На восьмому саміті (Нью-Делі, 2-4 травня 1995 р.) глави держав чи урядів відзначили, що неграмотність є однією з основних причин бідності, відсталості та соціальної несправедливості і закликає держави-члени ініціювати більш конкретні програми, спрямовані на ліквідація неграмотності у регіоні переважно до 2000 р. Лідери вирішили дотримуватися 1996 року як «Рік грамоти СААРК». Щоб підвищити рівень грамотності в регіоні, визнаючи ресурсні, людські та інфраструктурні обмеження для просування професійно-вищої освіти в регіоні, лідери на дев'ятому саміті (Мале, 1214 травня 1997 р.) погодилися, що нові та інноваційні методи «Відкрите навчання та дистанційна освіта» можуть відігравати ефективну роль у задоволенні регіональних потреб економічно ефективним та гнучким способом. Відповідно, лідери погодилися, що інституційні засоби в такій освіті, які є в регіоні, повинні використовуватися в регіональному масштабі. Також слід вивчити можливість створення Консорціуму відкритих університетів у регіоні ${ }^{19}$.

У рамках регіонального співробітництва у галузі культури Непал і Пакистан вперше зустрілись під час Технічного комітету з питань спорту, мистецтв і культури, що відбулася у Нью-Делі в січні 1989 р. 3 тих пір вона була важливою сферою співпраці між країнами у СААРК. Десятий саміт (Коломбо, 29-31 липня 1998 р.) Визнав глибокий культурний континуум Південної Азї̈ як історичну основу для підтримки гармонійних відносин між народами регіону і привітав пропозицію Шрі-Ланки провести зустріч міністрів культури з метою, серед іншого, створення Центру культури Південної Азії. У листопаді 2001 р. в Коломбо відбулося підготовче засідання секретарів 3 питань культури, в якому було рекомендовано практичні заходи, зокрема, для охорони, збереження та підтримки культурних і паломницьких місць; розвиток археології та музикознавства; заохочення сучасного мистецтва та культури; залучення корпоративного сектору та недержавних організацій до культурної діяльності; розвиток коопераційних зв'язків з ООН та іншими регіональними установами.

Зустріч міністрів культури (Коломбо, 5-7 лютого 2003 р.) затвердила заходи щодо захисту, збереження та збереження культурної спадщини Південної Азї, а також співпрацю між державами-членами у просуванні сучасного мистецтва та культури. У вересні 1999 р. в Шрі-Ланці пройшов перший кінофестиваль СААРК. 3 цього приводу було також проведено три семінари, присвячені різним аспектам кінематографу Південної Азї̈, включаючи фільм як культурне вираження, кінематографічний маркетинг та дистрибуцію, а також майбутнє кіноіндустрії. Ще один кінофестиваль відбувся в Шрі-Ланці у грудні 2004 р. Затверджено Рекомендації Технічного комітету 3 прав людини на першому засіданні (Коломбо 4-5 березня 2004 р.) про те, що кінофестивалі СААРК можуть бути організовані щорічно державами-членами. Це значною мірою сприяє просуванню культури серед країн СААРК, зокрема між Непалом та Пакистаном. Лідери під час Дванадцятого саміту (Ісламабад, 4-6 січня 2004 р.) пишалися багатою культурною мозаїкою народів Південної Азії і підкреслювали необхідність збереження традиційних навичок і ремесел, а також сприяння культурним обмінам між народами.

Під час тринадцятого саміту (Дакка, 12-13 листопада 2005 р.) лідери визнали вирішальну роль культури у наближенні людей Південної Азії. Вони також підкреслили, що співпраця у сфері культури є життєво важливою для зміцнення та проектування чіткої ідентичності Південної Азії. Міністрам культури СААРК було доручено найближчим часом зустрітися для розробки порядку денного СААРК для культури ${ }^{20}$.

${ }^{19}$ South Asian Association for Regional Cooperation (2019). Education security and culture. Retrieved from http://saarc-sec.org/areas_of_cooperation/area_detail/education-security-andculture/click-for-details_11

${ }^{20}$ Delinic, T. (2011). Op. cit., 56. 
Також на тринадцятому саміті СААРК глави держав чи урядів доручили міністрам культури СААРК якомога швидше зустрітися з метою розробки порядку денного СААРК для культури. Відповідно, на запрошення уряду Шрі-Ланки 31 жовтня 2007 р. в Коломбо відбулося Друге засідання міністрів культури. На засіданні були розглянуті питання створення культурного центру СААРК у Шрі-Ланці та створення Музею текстилю та ремесл СААРК в Індії, Програми СААРК з питань культури, охорони, збереження та збереження культурної спадщини Південної Азї, включаючи нематеріальну культурну спадщину. у Південній Азії, розширення співпраці між державамичленами у просуванні сучасного мистецтва та культури в Південній Азії, пропаганда культурного туризму, паломників, проведення культурних фестивалів, кінофестивалів тощо, а також співпраця з міжнародними організаціями ${ }^{21}$.

У політичному сенсі Непал і Пакистан залишалися добрими друзями протягом десятиліть. Пакистан висловив підтримку демократичних перетворень у Непалі та руху Джана Андолана 2006 р. Пакистан привітав відновлення діяльності парламенту Непалу і висловив надію, що ця подія відкриє епоху тривалого миру і процвітання в Непалі. При цьому, Пакистан заявляв про свою підтримку суверенітету, територіальної цілісності і мирного розвитку Непалу.

У рамках гуманітарної співпраці Пакистан надає допомогу Непалу у багатьох сферах. Пакистанська місія в Катманду надає медичне обладнання, включаючи машини швидкої допомоги, різним лікарням в Непалі. Крім того, він передав компютерне обладнання ряду установ, швейні та в’язальні машини різним організаціям і книги для певних бібліотек. Однак найважливішим пожертвуванням з Пакистану була очна лікарня Бхаратпур на 50 ліжок у Читване, яка була побудована близько 21 рік тому і обслуговує близько 1,5 мільйонів чоловік. На додаток до всіх видів співробітництва, згаданим вище, дві країни також надають одна одній надзвичайну допомогу в разі стихійних лих. Непал відправив партію гуманітарної допомоги, коли в жовтні 2005 р. у північній частині Пакистану стався землетрус, і пожертвував 10 млн. рупій.

Отже, відносини Непалу та Пакистану протягом XX - початку XXI століття можна охарактеризувати як динамічні: від активного політико-економічного та культурного діалогу до розкриву дипломатичних відносин. Непал і Пакистан залишалися добрими друзями протягом десятиліть. При цьому, Пакистан заявляв про свою підтримку суверенітету, територіальної цілісності і мирного розвитку Непалу. В Організації Об'єднаних Націй та інших міжнародних форумах Пакистан і Непал координують свої позиції і підтримують кандидатури один одного. Лідери Пакистану та Непалу завжди зустрічаються в кулуарах міжнародних конференцій.

\section{REFERENCES}

Ahmad, S. (2007). Pakistan's Foreign Policy. Lahore: Daily Nation. [in English]

Ahmed, S. (2009). Foreign Policy of Pakistan and Policy Making Process. In M. Ahmar, Foreign Policy Making Process; A Case Study of Pakistan. Islamabad: University of Karachi: Department of International Relations in Collaboration with Hanns Seidel Foundation. [in English]

Amin, S. (2009). Historical Basis of Pakistan's Foreign Policy Making Process. Islamabad: University of Karachi: Department of International Relations in Collaboration with Hanns Seidel Foundation. [in English]

Delinic, T. (2011). SAARC-25 Years of Regional Integration in South Asia. KAS International Reports. [in English]

Embassy of Pakistan Kathmandu. (n.d.). Pak-Nepal Economic Relations. Retrieved from http://pakembnepal.org.pk/pak-nepal-economic-relations/ [in English]

Government of Nepal - Ministry of Foreign Affairs (2019). Nepal-Pakistan Relations. Retrieved from https://mofa.gov.np/nepal-pakistan-relations/ [in English]

Hudson, V. (2008). The History and Evolution of Foreign Policy Analysis. In S. Smith (ed.), Foreign Policy: Theories, Actors, Cases (pp. 47-56). Oxford University Press. [in English]

${ }^{21}$ South Asian Association for Regional Cooperation (2019). Education security and culture. Retrieved from http://saarc-sec.org/areas_of_cooperation/area_detail/education-security-andculture/click-for-details_11 
Kaler, S. (2016). Successes and Failures of SAARC. Indian journal of applied research, 6 (3), 212213. DOI: 10.36106/ijar [in English]

Library of Congress. (n.d.). Pakistan and Bangladesh. Retrieved from http://countrystudies.us/nepal/66.htm [in English]

Nepal-Pakistan friendship and cultural Association. (n.d.). Pakistan-Nepal Relations. Retrieved from http://npfca.org.np/history-of-nepal-pakistan-relations [in English]

Sattar, A. (2010). Pakistan's Foreign Policy (1947-2009): A Concise History. Karachi: Oxford University Press. [in English]

South Asian Association for Regional Cooperation (2019). Education security and culture. Retrieved from http://saarc-sec.org/areas_of_cooperation/area_detail/education-security-andculture/click-for-details_11 [in English]

Iryna Habro,

ORCID: https://orcid.org/oooo-ooo1-8215-7615 Petro Mohyla Black Sea National University, Mykolaiv, Ukraine

Yelyzaveta Kabachek, ORCID: https://orcid.org/oooo-0002-0746-6239 Petro Mohyla Black Sea National University, Mykolaiv, Ukraine

\section{Peculiarities of the relationship between Nepal and Pakistan in the XX - early in the XXI century}

Pakistan and Nepal are South Asian states that are members of the South Asian Regional Cooperation Association. Pakistan is a heavily populated, militarized state with a nuclear arsenal. Nepal is a small country in the Himalayas that does not have a large arsenal of weapons. Both states were officially established in the mid-twentieth century. Conflicts on the border between Pakistan and India continue to erupt. Nepal, which is partially dependent on India, cannot always condemn its actions, if it wants to maintain good relations with Pakistan. Pakistan-Nepal's relations have been volatile during the $X X$ - at the beginning of the XXI century - from friendly relations to the breaking of diplomatic relations. However, Nepal is a strategically important territory for Pakistan. In spite of poor transport links, Pakistan prioritizes increasing trade and revitalizing relations with Nepal, as such developments will drive India out of this area, with the geopolitical map of the world undergoing change and India losing its dominant position. Both Pakistan and Nepal play an active role in SAARC, reflecting, in essence, their shared desire to promote peace and progress in South Asia.

The article describes the relationship between Pakistan and Nepal in the twentieth century. In the course of the work, the history of Nepal-Pakistan relations was investigated, the peculiarities of cooperation within the Association of Regional Cooperation of South Asia were explored, economic and cultural cooperation was studied. The specifics of Nepal-Pakistan relations are hardly revealed in the works of national scientists, which is relevant to this research.

Keywords: Pakistan, Nepal, South Asian, SAARC, economic cooperation, political cooperation 